\title{
O ENSINO DE HISTÓRIA - ALGUMAS REFLEXÕES DO REINO UNIDO: entrevista com Peter J. Lee
}

\section{Cristiani Bereta da Silva*}

O interesse em publicar uma entrevista com o professor Peter Lee vem ao encontro do desejo de fazer circular ainda mais suas pesquisas e reflexões sobre como as crianças e jovens elaboram ideias sobre a história, no Brasil. Tal desejo parte do pressuposto de que o ensino de História na Educação Básica pouco ou nada avançará sem que os professores e pesquisadores da área considerem seriamente a questão da aprendizagem, ou melhor, os processos cognitivos envolvidos na construção do pensamento histórico. Processos que implicam compreender como os sujeitos elaboram as ideias históricas e como constroem percepções sobre o passado. Com esta entrevista espera-se também contribuir com o debate sobre as formas e funções da história na vida cotidiana, pois se postula aqui - e a discussão de Peter Lee também atenta para isso - que a história é uma forma de pensar e interpretar a existência humana, no tempo. Além de sua forma acadêmica, disciplinar, a história também é uma forma pública de conhecimento. Essas dimensões que se articulam e se entrecruzam em diferentes planos constituem a consciência histórica dos indivíduos e coletividades. Irrenunciável, portanto, que pensemos nos desafios daí advindos, sobretudo aqueles relacionados ao ensino de História nas escolas. Sobretudo se se quer e acredita que o ensino de História é uma ferramenta poderosa, capaz de possibilitar a leitura do mundo, de potencializar formas de habitar e de existir articuladas à construção de pertencimento a uma coletividade e a um projeto de futuro comum.

\footnotetext{
* Doutora em História pela Universidade Federal de Santa Catarina. Professora da Universidade do Estado de Santa Catarina. E-mail: cristianibereta@gmail.com
} 
Peter Lee foi ${ }^{1}$ professor na Unidade de Educação Histórica, no Instituto de Educação da University of London. Antes disso, ele ensinava história em escolas primárias e secundárias, o que certamente contribuiu para a formulação de grande parte de suas questões de pesquisa. O professor Lee coordenou vários projetos de investigação relacionados ao ensino e aprendizagem de História, o mais conhecido deles no Brasil é o Chata (Concepts of History and Teaching Approaches). Os resultados dessas pesquisas foram publicados em vários livros, capítulos e artigos. Muitos desses trabalhos são em coautoria com Rosalyn Ashby. Alguns de seus artigos foram traduzidos para o português e circulam entre os pesquisadores preocupados em compreender como as crianças aprendem história, no Brasil. As questões desta entrevista foram elaboradas com a intenção de que as reflexões de Peter Lee colaborem com o desenvolvimento das pesquisas relacionadas ao ensino de História no Brasil. Todos os contatos foram feitos por e-mail, ferramenta absolutamente útil e que rompeu, por alguns demorados instantes, entre julho e outubro de 2012, a distância entre Florianópolis e Londres.

Tempo e Argumento: O projeto Chata (Concepts of History and Teaching Approaches) é citado com frequência no Brasil em razão da importância de se investigar as ideias que as crianças e jovens possuem. Você pode, por favor, falar um pouco mais sobre este projeto para os leitores brasileiros? Há algum outro projeto semelhante em curso no momento, na Inglaterra?

Peter J. Lee: O projeto Chata só pode ser entendido como parte de uma tradição mais ampla de pensar a história e o entendimento das crianças sobre a história que se desenvolveu no Reino Unido por volta de 1960. (Mais precisamente, devo dizer na Inglaterra, porque a Escócia e a Irlanda do Norte têm seus próprios sistemas educacionais, e o País de Gales sempre teve sua perspectiva própria).

W.H. Burston no Instituto de Educação da University of London acredita que o ensino de História deve ser informado - se pretende ser um ensino genuíno de história - pela análise da história fornecida pelos filósofos da história. Ele se baseou no estudo de W.H. Walsh, em particular, e foi até certo ponto influenciado por seu amigo Michael Oakeshott. Ele também reconheceu que o ensino de História não iria nunca prosperar se não levasse a sério o aprendizado e o desenvolvimento cognitivo, e aqui sua relação próxima com Edwin Peel da

\footnotetext{
${ }^{1}$ Ele se aposentou recentemente, conforme indica no final dessa entrevista.
} 
Universidade de Birmingham foi de central importância. O estudo de Peel deve muito ao estudo de Piaget, mas voltou sua atenção às “disciplinas” específicas da escola, inclusive a História.

A importância de Burston não estava nas recomendações particulares que ele ofereceu ao ensino de História, mas na sua posição básica: saber que era essencial reconhecer as contribuições da filosofia da história e da psicologia cognitiva e de desenvolvimento para qualquer tentativa séria de reflexão sobre a natureza e o lugar da história na Educação. Burston incentivou o seu colega, Donald Thompson (que foi aluno de Burston) e um grupo de alunos do curso de Mestrado a começarem um programa de estudo empírico para investigar o pensamento dos alunos sobre história. Thompson produziu vários trabalhos sobre o pensamento histórico dos alunos e começou um estudo de doutorado importante sobre a organização de acontecimentos da história - por meio de agrupamentos colligatory ${ }^{2}$ - por alunos (em pequena escala), mas nunca completou ou publicou seu trabalho. Alaric Dickinson, também um aluno de Burston, se interessou pela avaliação do pensamento das crianças.

Eu fui influenciado tanto por Burston (de quem fui aluno depois que sai de Oxford) como por Thompson, mas também por algumas experiências no ensino de um grupo de alunos de 13 e 14 anos. Tanto nas minhas turmas como em inúmeras aulas de outros professores - que a minha posição no Instituto de Educação me permitiu assistir - ficava aparente que os alunos frequentemente consideravam as pessoas do passado como um tanto burras e até moralmente fracas. A origem de tal fato parece estar na vontade dos alunos de sugerir caminhos alternativos que os agentes históricos poderiam 'facilmente' ter seguido, mas que falharam no desempenho de suas ações. (Por exemplo, a ideia de que Chamberlain deveria ter dado um soco na cara de Hitler ao invés de se submeter aos seus ataques raivosos e oferecer um desastroso compromisso em forma do acordo de Munique.) Isto me levou a considerar como seria possivel para os alunos pensar que tais ações alternativas seriam factíveis. A análise de Dray, dos motivos para a ação, forneceu uma base para o reconhecimento das complexidades envolvidas em seguir as explicações históricas, as quais, além de apelar para as intenções, pressupunham um conhecimento das convenções e regras sociais, e do contexto situacional. Estudos piagetianos e pós-piagetianos enfatizaram a

\footnotetext{
2 Segundo Ola Hallden o conceito de colligatory é oriundo da Física e foi introduzido na Filosofia da História por W.H Walsh. Colligatory é um conceito de ordem superior, que traz uma série de eventos, descrevendo-os em conjunto a partir de um aspecto que os torna inteligível ou relevante na explicação. Revolução Francesa, Revolução Industrial, Iluminismo, por exemplo, trazem em si uma série de eventos relacionados e fornecem os subsídios necessários para uma compreensão da história (HALLDEN, 1997, p.204). Nota: Cristiani Bereta da Silva.
} 
dificuldade de ver as situações com base em outras perspectivas, e na história esta dificuldade foi composta pelas diferenças entre as maneiras de se enxergar as coisas no passado e a nossa própria maneira, no presente.

No início dos anos 1970, utilizando um quadro conceitual que desenvolvi, principalmente com base em Collingwood, Dray e G.H. Von Wright, Alaric Dickinson e eu, investigamos as explicações de alunos sobre a decisão tomada pelo Almirante Jellicoe para se desviar dos alemães no auge da batalha de Jutland na Primeira Guerra Mundial, assim que a frota alemã parecia correr risco de ser destruída. Alaric e eu continuamos a olhar para as explicações dos alunos em um contexto concreto diferente, que foi o da destruição por Henrique II dos falsos castelos, mas decidimos que os métodos de lápis, papel e entrevistas eram limitados. Nós, então, desenvolvemos nossas técnicas de pesquisa utilizando câmeras de vídeo para gravar pequenos grupos de alunos trabalhando com problemas históricos com pouca intervenção (e eventualmente nenhuma) de adultos. (Estes foram 'problemas' no sentido que os alunos tinham uma tendência a ver as instituições ou ações em questão como muito estranhas: por que, por exemplo, os hilotas não derrubaram seus mestres espartanos, ou por que, no tempo dos anglo-saxões, as pessoas empregaram a ajuda de juramentos e provações como forma de decidir se os acusados eram culpados pelos crimes?) As pesquisas foram feitas com alunos de escolas de ensino primário e secundário, com idades entre 8 e 16 anos.

Em termos de pesquisa, o resultado mais importante foi a mudança de tentar ir atrás da lógica de pensamento, para tentar entender a base conceitual do entendimento histórico dos alunos. Quais eram as ideias de segunda ordem com as quais eles operavam? Como, por exemplo, eles constroem a base do conhecimento histórico: eles tinham algo como um conceito histórico de evidência, ou eles estavam tratando a história simplesmente como uma informação dada? (Utilizamos a 'segunda ordem’ aqui para distinguir, por um lado, os conceitos implícitos por trás da abordagem dos historiadores em relação a qualquer conhecimento do passado, por outro, pelas suas alegações concretas sobre qualquer parte em particular do passado. Outra forma de colocar isto é distinguir a história como uma forma de conhecimento ou uma ‘disciplina’, de seu ‘conteúdo’ — as frases e histórias sobre o passado que os historiadores produzem quando eles fazem a história.).

Logo após o nosso primeiro trabalho sobre o que agora chamam de 'empatia' (mas que talvez devesse ser chamado de 'entendimento racional'), publicado no inicio de 1978, Alaric Dickinson e eu encontramos Denis Shemilt, que tinha sido convidado para dar uma palestra aos nossos alunos sobre o Schools Council History Project (SCHP). Nós todos logo 
percebemos que estávamos perseguindo, de forma independente, hipóteses semelhantes, e Denis nos falou que os professores no SCHP tinham declarado que nossos resultados iniciais da tarefa de Jutland pareciam se repetir no trabalho em sala de aula. Ficamos todos animados ao descobrir que os estudos independentes de Londres e Leeds apresentavam resultados muito parecidos. (É importante enfatizar neste ponto que os pesquisadores de Londres jamais foram parte da equipe do SCHP, apesar de afirmações ao contrário em alguma literatura!).

No início dos anos 1980 comecei a trabalhar em uma escola secundária de Essex com Rosalyn Ashby (que foi minha aluna) fazendo gravações de vídeo de alunos em vários momentos durante a semana. Nós acompanhamos várias aulas durante mais de três anos (com alunos de 11 anos de idade em diante), ensinando junto, coletando dados de pesquisa de pequenos grupos e, eventualmente, integrando a gravação de vídeo em discussões em sala de aula que às vezes duravam várias aulas de 90 minutos cada. (Os alunos aprenderam com habilidade considerável a gravar as aulas e discussões sozinhos, utilizando a câmera e um microfone parabólico.).

Durante este período de contato, Londres e Leeds se tornaram bem próximas, e no final dos anos 1980 Rosalyn Ashby e eu, juntamente com as equipes de professores do norte e sul da Inglaterra, nos envolvemos com Denis Shemilt no desenvolvimento de um curso de acompanhamento para estender, o que foi neste estágio simplesmente chamado de O Projeto de História nas Escolas. Este curso de acompanhamento ficou conhecido como o Projeto de História de Cambridge, um novo Nível Avançado de exame de curso para alunos entre 16-18 anos, cujo objetivo era melhorar o entendimento e o conhecimento de história dos alunos ao desenvolver seus entendimentos de segunda ordem. Uma vez que isto estivesse ocorrendo como um curso piloto para o exame em escolas, eu me voltei (com Rosalyn Ashby e Alaric Dickinson) para o projeto Chata com sede em Londres, enquanto Denis Shemilt ficou cada vez mais concentrado em um periodo de trabalho administrativo em Trinity e All Saints College em Leeds.

Deve ficar óbvio com base nisso, e especialmente da menção da pesquisa com o vídeo em sala de aula, que o Chata veio de uma pesquisa em sala de aula muito extensa e prolongada (talvez mais do que qualquer outra que já foi feita em escolas inglesas). Enfaticamente, não foi uma pesquisa desligada do aprendizado em sala de aula (e afirmações mal orientadas de um ou dois comentadores de que se usou uma metodologia 'experimental' apenas traem um entendimento estranhamente idiossincrático do que constitui um experimento). O Chata foi planejado para acompanhar o trabalho inicial com base na televisão em sala de aula, escolhendo usar métodos mais tradicionais com lápis e papel e 
entrevista para lidar com uma amostragem grande (mais de 300 alunos). Um objetivo importante foi de testar o quadro preliminar advindo do estudo com vídeo e sala de aula, e especialmente do longo programa de ensino que Rosalyn Ashby e eu tínhamos realizado em Essex, para ver se se mantinha o resultado com uma gama maior de alunos, e com uma gama de conteúdos diferentes. Assim foi tomada a decisão de pedir para que os alunos completassem três conjuntos de tarefas distintos, cada um deles lidando com quatro diferentes conceitos-chave de segunda ordem no contexto de conteúdos históricos concretos bem distintos. Como resultado desta metodologia o Chata gerou uma enorme quantidade de dados, e alguns deles nunca foram analisados (principalmente porque mudanças na situação do Instituto de Educação impossibilitaram a equipe de pesquisa de usar o tempo que teria sido necessário). Contudo, foi possível produzir um trabalho sobre os quatro conceitos-chave, e isto foi publicado em inúmeros trabalhos no mundo todo.

No que diz respeito à sua pergunta sobre a situação atual, eu não estou a par de qualquer pesquisa dentro desta tradição que esteja acontecendo no momento no Reino Unido, com uma exceção importante. Arthur Chapman está desenvolvendo seu estudo de doutorado sob a influência do Chata, a respeito das ideias dos alunos sobre relatos históricos, usando abordagens inovadoras com base na internet, na qual os alunos discutem relatos concorrentes. (Uma característica particularmente importante deste trabalho é que os historiadores profissionais se envolvem com os alunos nas conversas online: por esta e por outras razões, a pesquisa está intimamente ligada ao aprendizado.) Esta pesquisa tem potencial para levar o nosso entendimento muito além das descobertas iniciais do Chata.

A afirmação de que eu não conheço nenhuma pesquisa atual com exceção desta de Chapman no Reino Unido seguindo a tradição de Londres-Leeds é correta, mas é, todavia, ligeiramente enganosa, por dois motivos. Primeiramente, estudos com objetivos e hipóteses semelhantes têm sido realizados em muitos países (com frequência, porém nem sempre, realizados por pesquisadores que foram treinados em/ou que tenham ligações com Londres) — especificamente no Canadá, Grécia, Portugal, Singapura, Espanha, Tailândia e nos EUA. Como vocês sabem, Isabel Barca tem seguido esta agenda com enorme empenho em Portugal, e isto também tem ajudado a aumentar o interesse em algumas pesquisas do Reino Unido no Brasil. Em segundo lugar, o foco na pesquisa inglesa mudou para os conceitos dos alunos sobre quadros mais abrangentes do passado: em que medida e de que maneira eles se relacionam a um conhecimento mais ou menos coerente do passado, presente e futuro. Denis Shemilt, Francis Blow e Rick Rogers em Leeds estão desenvolvendo trabalhos sobre isto. Eu realizei algumas pesquisas de pequeno porte nesta área no início dos anos 2000, e ajudei a 
orientar um pequeno projeto em Londres envolvendo Jonathan Howson, Stuart Foster, Rosalyn Ashby e relatei isto em 2008. Contudo, Denis Shemilt é o inovador e o condutor por trás dos estudos atuais a respeito destes problemas.

Duas facetas dos 'quadros abrangente' e das estruturas do passado requerem estudo simultâneo: primeiramente, como fornecer as visões que irão permitir aos alunos construir um 'quadro abrangente' do passado adequado às finalidades de orientação; e segundo, como as ideias dos alunos de conceitos-chave centrais para tais 'quadros abrangentes' se desenvolvem. Exatamente o que são estes conceitos será determinado apenas com o prosseguimento da pesquisa, mas noções da escala, generalização e relatos históricos parecem ser centrais, e suspeito que algo semelhante à noção de Walsh de colligatory também possa ser importante. Mesmo nesta junção inicial é provavelmente seguro dizer que as ideias a respeito da natureza de relatos históricos desempenham um papel principal.

Tempo e Argumento: As pesquisas realizadas no âmbito da Educação Histórica, no Brasil, cuja principal referência é o Laboratório de Pesquisa em Educação Histórica (LAPEDUH) da Universidade Federal do Paraná (UFPR), têm se apoiado principalmente nos trabalhos de Jörn Rüsen. Em seu artigo 'Walking backwards into tomorrow'. Historical consciousness and understanding history" há uma importante reflexão sobre até que ponto a teoria de Rüsen pode ser útil ou problemática para pensarmos o papel do ensino de História em orientar os jovens no tempo. Você pode falar um pouco mais sobre o tema?

Peter J. Lee: Preciso ter cautela aqui. Muito pouco do trabalho de Rüsen foi publicado com tradução em inglês, e minha capacidade de ler em alemão é mais ou menos zero. Portanto qualquer comentário que eu tenha feito, ou que faça agora, deve ser tratado como de um ‘intrometido’ que só tem acesso a pequenas porções das evidências disponíveis. Esta situação significa que eu não posso falar com segurança sobre a base teórica mais ampla do trabalho de Rüsen. Se não para repetir pontos que já tenha colocado em 'Walking backwards', vou só costurar alguns problemas suspensos nesta discussão que precisamos urgentemente abordar.

A característica chave do trabalho de Rüsen em inglês, com base numa perspectiva de Londres-Leeds no Reino Unido, é a maneira na qual ele oferece uma visão de história e educação histórica que leva a história a sério ao relacionar a abordagem histórica do passado com problemas de orientação e identidade. Rüsen reconhece que a história muda com o tempo, e é informada por preocupações diárias da vida no mundo, mas também reconhece que ela tem suas próprias regras e práticas metodológicas (produzindo um 'excedente teórico’), e 
que pode, portanto, ter um ponto de vista crítico direcionado a interesses e demandas da vida prática.

A natureza da história como uma forma de ver o mundo (e que pode transformar como os alunos veem a si mesmos no tempo e como concebem a possibilidade e o status do conhecimento do passado) é, claro, central para a educação histórica. O tratamento que Rüsen dá à história é imensamente mais sutil e penetrante do que algumas das concepções de 'estudos sociais’ populares nos Estados Unidos (e em outros lugares). O tipo de concepções de 'estudo social' que eu tenho em mente aqui defende que a história na escola não é a 'mesma' que a história acadêmica, que a história acadêmica é meramente um resultado da especialização institucional do século dezenove, que, portanto não pode reivindicar uma distinção dos (ou mesmo dentre os) estudos sociais e que, consequentemente, a história não pode ter um lugar justificavel nas escolas, exceto como um meio de promover cidadãos democráticos. Eles também tendem a fazer reivindicações um tanto sombrias sobre quaisquer relações entre a história 'acadêmica' e a 'matéria' da escola (uma noção em si que fica imensamente vaga), mas parecem querer insistir que essa 'disciplina' tem apenas uma relevância limitada para a educação histórica.

O principal peso destas reivindicações parece ser que a história 'acadêmica’ não tem o status privilegiado em relação à memória coletiva ou qualquer outra fonte de relatos do passado. Contudo, os que apoiam uma abordagem de 'estudos sociais' ainda parecem ser incapazes de evitar invocar algo bem parecido com isto como a base do que deveria ser ensinado. Por exemplo, eles ainda querem afirmar que as narrativas devem se basear em evidências, e enfatizam em suas demandas para a reforma do ensino de História que os alunos devem aprender como usar a evidência histórica, apesar de falharem ao tratar de questões necessárias da relação entre as evidências e os relatos. É claro que é bem mais simples fazer algumas confusões aqui se a caracterização de história como 'acadêmica' já parece denotar um público restrito e possivelmete uma atividade esotérica inadequada para pessoas leigas, imagine então para crianças ou jovens. As suposições por trás desta visão parecem ser menos baseadas em evidência empirica (alguns seguidores desta abordagem dos 'estudos sociais' têm produzido evidências de pesquisas valiosas com um olhar positivo para o que seria possível para os alunos), mas sim em crenças, a priori, sobre a natureza da educação e da história ‘acadêmica'. Quando eles afirmam que a história ‘acadêmica’ é um desenvolvimento social como muitos outros, não parece ocorrer a eles que as conexões sociais entre a abordagem 'acadêmica' e outras em relação ao passado não são separadas por uma barreira. Nossas maneiras de ver o mundo são todas no tempo, e o ‘senso comum’ também não é fixo. 
A história 'acadêmica' mudou a maneira como nos relacionamos com o passado, e isto aparece precisamente nas agendas recentes de mudança na abordagem de 'estudos sociais', nas quais o que conta como fazendo uma boa história é deixado de lado como sendo um meio de melhorar o ensino, mesmo quando a sua importância é descartada.

Precisamos ter alguma concepção do que conta como história, mas não há um grande ganho em se debater sobre se a concepção de história com a qual se opera na educação é 'acadêmica', muito menos se isto dispensa objetivos 'disciplinares' que sejam óbvios ou inconsequentes ou (de alguma maneira paradoxal) como ambos. É claro que a história está por si só no tempo, e o crescimento de uma universidade formal baseada na disciplina é uma indicação das mudanças em nossas abordagens em relação ao passado. Contudo, não vem do fato de os departamentos de história existir em universidades que a 'história' seja apenas para os acadêmicos, ou que os tipos de reflexão sobre o passado que acontece nas universidades não sejam relevantes para qualquer um fora destas instituições.

Em total contraste com a concepção de 'estudos sociais', Rüsen não adota uma visão restrita e pejorativa de história acadêmica, mas igualmente ele não a privilegia. Pelo contrário, ele oferece uma discussão complexa e interessante sobre as relações entre a história acadêmica e outros componentes da consciência histórica. Ele reconhece que existem diferentes interesses em jogo em como nós escolhemos abordar o passado. (Outra maneira de colocar isto — não tenho certeza até que ponto seria aceitável para Rüsen — seria dizer que questões diferentes levam a diferenças nos tipos de passados que construímos). E é por isso que a sua posição é muito mais produtiva do que os pontos de vista dos ‘estudos sociais’ que só entendem qualquer papel da história na escola em termos de suas contribuições para tornar os alunos democráticos.

O ponto não é, claro, que a história seja oposta ou separada dos valores democráticos, mas que ela nunca pode ser justificada simplesmente como um instrumento para a criação de democratas. Isto porque, se fôssemos reivindicar seriamente que o papel da história na escola fosse criar bons democratas, e se ficasse claro que alguns alunos 'falharam' em se tornar democratas, então nós teríamos que consertar a história para garantir que ela desempenhasse o seu trabalho. Em outras palavras qualquer evidência empírica de que o objetivo de produzir democratas não estava sendo cumprido iria demandar que a história que estávamos ensinando fosse revisada até que ela garantisse que esta situação fosse retificada. Neste ponto a história deixaria de ser história e se tornaria outra coisa qualquer, talvez alguma forma de 'educação para a cidadania', mas com o perigo de cair em algo como propaganda. Todavia, fazer com que alunos se adaptem a algum modelo de cidadania é um objetivo muito diferente de 
capacitá-los a se distanciar e desafiar tanto este modelo como a tentativa de convencê-los a se conformar com qualquer modelo em particular. Não é que a educação para a cidadania seja ilegítima, mas sim que ela faz um trabalho diferente daquele da educação histórica, e confundir as duas simplesmente destroe a possibilidade de garantir uma educação histórica. Podemos garantir democratas, ou podemos garantir a história, mas não ambos simultaneamente - um tipo de 'princípio de incerteza' para a educação histórica.

Na verdade a história não é um instrumento para criar certos tipos de cidadãos, não importa o quão nobre tais objetivos pretendam ser. Sua relação com a democracia é muito mais interessante do que isto, a história e a democracia são características de uma sociedade aberta. A história pode ser necessária para o funcionamento bem sucedido de uma democracia, e a democracia pode ser uma forma de arranjo social e político que permite a história. Mais importante, a história compartilha alguns valores importantes com a democracia: ela presupõe liberdade para dar o melhor argumento, ela assume abertura para discussões com base em evidência e ela pressupõe tanto respeito pelas pessoas e igualdade para as pessoas como fontes para discussões. O aprendizado da história pode provavelmente incentivar alunos a levar a democracia a sério, mas isto está muito longe de significar que o seu papel na educação tem que ser o de um instrumento para produzir democratas.

Nem seria o caso da história (entendida como parecida com a história 'acadêmica') simplesmente superar ou dominar outros tipos de passados. Muitas perguntas que nos fazemos sobre o passado começam baseadas em preocupações práticas e éticas. Elas não se tornam ilegítimas pelo fato de ser possível abordar o passado em resposta a diferentes tipos de questões que não estão baseadas de nenhuma forma direta aos nossos interesses práticos (em qualquer um dos sentidos desta palavra). Da mesma forma, temos motivos práticos e éticos para defender posições extremas sobre algumas ações do passado, e podemos tirar 'lições' práticas sobre como deveríamos nos comportar na leitura do passado (mais sobre isto em resposta a uma pergunta abaixo), e a história não rege isto. Não há uma hierarquia fixa de abordagens em relação ao passado na qual a história sempre saia 'por cima'. O ponto é que questões diferentes feitas por motivos diferentes requerem diferentes tipos de abordagens. Se o nosso propósito principal ao perguntar sobre o passado é tentar garantir a coesão social ao fornecer um passado inspirador em comum - uma história compartilhada da qual ‘nós’ (não importa quem em qualquer caso em particular) possamos nos orgulhar, então a história pode passar a ser inferior a outras formas de consciência histórica. A 'memória coletiva' de um grupo étnico ou cultura pode ser imensamente mais útil como um meio de resistir à hegemonia cultural de outra cultura do que qualquer exploração histórica. 
Uma forma de olhar o passado que não permita a ninguém possuí-lo, e mais ainda exija que aceitemos histórias que vão contra os nossos interesses práticos e até os nossos sentimentos mais profundos — sejam estes relacionados à identidade, feridas e encargos, ou mesmo triunfo - permite leituras do passado que abrem caminhos diferentes daqueles exigidos pelos nossos interesses práticos. Pode mesmo mudar o sentido de quem somos, o que podemos e não podemos fazer, e até mesmo nossas crenças sobre o que pode ser estabelecido como fato. Neste sentido há uma maneira (talvez muitas) de se olhar para o passado que é diferente das outras, e não importa se a chamamos de 'história' ou outra coisa qualquer, contanto que reconheçamos que é diferente.

A alegação de que aqueles que afirmam a importância dos estudantes em compreenderem a 'disciplina' estão tentando antecipar pontos de vista alternativos por um truque de definição (se apropriando da palavra 'história'), portanto, baseia-se em um malentendido de como a história se relaciona com outras formas de consciência histórica. Não precisamos ser capazes de estabelecer regras rígidas sobre 'métodos' para discutir que a história desenvolveu maneiras cada vez mais poderosas de abordar suas tarefas, ou de tentar distinguir a história 'genuína' de algo que não é. É óbvio que não podemos sempre distinguir facilmente, e que não há uma linha divisória clara. Deparamo-nos com algo muito mais como um continuum: podemos dizer que os passados no final de cada linha sejam bastante diferentes, mas temos dificuldade quando eles parecem se mesclar uns com os outros. (Comparar a nossa distinção entre vermelho e azul, onde novamente não há uma divisão clara, mas que ainda podemos falar de maneira sensata sobre duas cores diferentes.) Um interesse (em ambos os sentidos) no passado pode iniciar um questionamento, mas então temos que começar a prestar atenção em quaisquer conceitos e ferramentas poderosas que estão realmente disponíveis.

Isto significa ir além da linha da matriz de Rüsen.

Rüsen leva a sério a relação entre a disciplina histórica que evoluiu como uma conquista duramente alcançada no último século ou mais e formas mais amplas de consciências históricas. Sua plataforma nos permite explorar as sutilezas desta relação, ao invés de estreitá-la da maneira como as abordagens de 'estudos sociais' tendem a fazer. Mas Rüsen também tenta ligar suas ideias sobre consciência histórica em todas as suas formas à educação, de maneira a promover a pesquisa dentro da ontogenia da consciência histórica. Novamente, isto vai além das considerações das abordagens de 'estudos sociais'.

Neste contexto o programa de pesquisa do Reino Unido em Londres-Leeds, sobre as ideias dos alunos a respeito dos conceitos de segunda ordem que estão por trás da história, 
tem algo em comum com os interesses empíricos implícitos no relato de Rüsen da ontogenia da consciência histórica, mas se concentrou de maneira firme nas ideias disciplinares-chave. Contudo, estudos recentes (particularmente em Leeds) sobre as ideias com as quais os alunos operam quando tentam dar sentido aos "quadros abrangentes" do passado podem abrir a perspectiva de perseguir algum tipo de conexão entre estas ideias e o desenvolvimento da consciência histórica. As concepções de alunos sobre os relatos históricos - a maneira como formam um sentido sobre os eventos ou processos ao longo do tempo, a natureza e o status dos conceitos 'colligatory' (como eles podem agrupar ou 'dividir' fenômenos), o status de relatos concorrentes e as implicações da existência de versões alternativas do passado para a segurança do conhecimento histórico ou a legitimidade das explicações históricas — parecem ter um papel central a desempenhar na maneira como - e no grau em que - os alunos podem lidar com os ‘quadros’ de longa duração do passado como um meio de orientação no sentido de Rüsen (Ver especialmente SHEMILT, 2009). Uma agenda importante de pesquisa futura é explorar como os alunos constroem relatos significativos sobre longos períodos da história de uma forma que lhes permitam relacionar passado, presente e futuro e, ao mesmo tempo, investigar os pressupostos que empregam ao fazê-lo. Isto incluiria suas pressuposições sobre como as sociedades humanas funcionam (conceitos substantivos) assim como concepções (por exemplo) da natureza e do status de relatos históricos, a atribuição do significado no interior de diferentes relatos e a relação entre as questões e os conceitos 'colligatory' (ideias de segunda ordem). Outra área frutífera de pesquisa poder ser: explorar o desenvolvimento de disposições que apoiem a história (ex. respeito pelas pessoas, consideração pela validade de discussões com base em evidência), construídos como 'paixões racionais' sem as quais os alunos não podem dizer que entenderam a história. Este tipo de agenda poderia conectar-se de maneira útil com aspectos das abordagens de Rüsen em relação à história e raciocínio moral.

Tempo e Argumento: No Brasil, embora haja parâmetros curriculares nacionais há grande heterogeneidade do que é ensinado em História na Educação Básica, mesmo em escolas de uma mesma cidade. No artigo "Towards a concept of Historical Literacy” traduzido $e$ publicado no Brasil em 2006, o senhor diz que "todos que conhecem qualquer coisa sobre educação histórica concordam de que há mais na história do que o conhecimento de lembranças de eventos passados, mas nem sempre há concordância sobre o que esse "mais” deveria ser”. Você pode falar um pouco mais sobre "o que ou como” deveria ser o ensino de História para crianças e adolescentes? 
Peter J. Lee: Esta parece ser uma pergunta sobre os objetivos da educação histórica, ou sobre o que é que poderia ou deveria ser ensinado em história. As respostas para isto irão depender de como construímos a história. Se o meu argumento anterior for aceito, a educação histórica pode ser vista como uma forma de conhecimento público duramente conquistado, em sua forma mais desenvolvida, como história acadêmica. Simples, alunos não são minihistoriadores (e a maioria não terá nenhuma intenção de se tornar historiadores acadêmicos). Ao viver suas vidas eles irão querer pensar no passado de várias maneiras, talvez como advogados procurando por ações legalmente válidas (ex. promessas ou contratos), ou talvez como membros de seitas religiosas, colocando suas crenças em tradições santificadas pelo passado. Eles poderão se tornar políticos ou diplomatas, procurando justificar suas políticas ou afirmar suas reivindicações de territórios com base no que eles podem encontrar no passado. Alguns deles podem querer insistir em se lembrar de feridas que ainda doem como resultado de maus-tratos de suas famílias, amigos ou de seu grupo social. Muitos deles irão provavelmente esperar que o passado lhes forneça exemplos de porque eles devem se orgulhar de sua nação. Todos estes são usos práticos legítimos do passado, mas nenhum deles representa uma abordagem histórica no sentido que eu tenho falado. Seria meramente bobo e simplista imaginar que a história na escola simplesmente substitui esta relação prática com o passado.

No entanto, a história como uma maneira de ver o mundo, uma forma pública de conhecimento e uma disciplina com o apoio de instituições acadêmicas, também tem a sua relevância na vida das pessoas. A história que não pertence a nenhuma pessoa ou grupo, e é responsável em suas reivindicações de uma tradição metacognitiva (mutante, multifacetada, mas reconhecidamente preservando sua identidade por meio das mudanças), nos permite ver o mundo de maneiras que não são fechadas por aquilo que gostaríamos de encontrar no passado, ou até o que esperamos encontrar. Alunos que estudam história são apresentados a uma maneira de pensar sobre o passado, presente e futuro que tenta tornar real frases factuais singulares sobre o passado, para dar as melhores explicações possíveis e para construir relatos válidos do passado, todos apoiados pelo uso não arbitrário de qualquer evidência disponível. Estas serão todas, é claro, relativas às perguntas feitas, iniciadas a partir de situações particulares, mas estas por sua vez também estarão abertas à crítica e ajustes em uma forma contínua de conhecimento público. Nenhuma das reivindicações de narrar fatos, para dar relatos válidos ou para oferecer as melhores explicações, será justificável por referência ao que os alunos quiserem crer, pelo que as autoridades (livros didáticos, professores, políticos, líderes religiosos) desejarem que eles acreditem, ou por apelo a propriedade de segmentos do 
passado. Ao aprender história os alunos começarão a aprender que nenhum relato final e fixo de nenhuma passagem do passado pode ser dado, mas que isto não significa absolutamente que todos os relatos sejam igualmente boas respostas para qualquer pergunta em particular, muito menos que possamos dizer o que gostamos a respeito do passado se nos satisfaz. Começarão a aprender que o passado histórico não é para ser saqueado para apoiar o que queremos dizer, mas deve ser encarado como algo com o que precisamos lutar e entender em que base na evidência que temos e foi explicado, de maneira que sejam abertas a teste.

Perguntar por que os alunos precisam aprender este tipo de abordagem do passado é como perguntar por que não devemos permanecer ignorantes, ou aprisionados por histórias cujas bases são convenientes para alguém ou algum grupo. É uma pergunta que já mostra a falta de compreensão sobre educação. E defender que os jovens não conseguem se ligar nisto e que estão melhores com as histórias fixas dos livros didáticos, ou listas de fatos desconexos, é fazer uma defesa empírica que não se sustenta e apelar para um conceito de aprendizado que não faz sentido. O entendimento nunca é tudo-ou-nada. Se fosse, então a maioria dos entendimentos dos adultos sobre o mundo natural não teria valor. $\mathrm{O}$ conhecimento dos políticos sobre história não contaria mais do que o de uma criança. A educação diz respeito à abertura de caminhos para ver o mundo, não para a produção instantânea de especialistas. E a pesquisa já sugere que os alunos realmente acham que é possível aprender história neste sentido.

Tempo e Argumento: Ainda no artigo "Towards a concept of Historical Literacy” você afirma que falta um conceito adequado de literacia ${ }^{3}$ histórica. Como esse conceito vem sendo desenvolvido em suas pesquisas e de que modo ele pode contribuir para que haja um pouco mais de consenso sobre o que ensinar de História?

Peter J. Lee: Esta pergunta é uma extensão da anterior. Talvez eu possa fazer uma pressuposição aqui de que o objetivo de se ensinar uma matéria na escola como História ou Ciências é ajudar os alunos a entenderem o mundo no qual eles vivem de maneira que os farão se desenvolver como seres humanos autônomos. Isto quer dizer que eles precisam tanto saber e entender algo do conhecimento que a História ou Ciência pode afirmar atualmente como, ao mesmo tempo, ter algum entendimento da natureza e dos status destas afirmações. Uma forma de olhar para isto é pensar no ensino das ‘matérias’ escolares como uma iniciação

\footnotetext{
${ }^{3}$ Optou-se por seguir a forma como se traduz o termo em Portugal.
} 
aos alunos nas tradições metacognitivas. Isto implica que a educação histórica deve envolver os alunos em

a) Aprender um conhecimento histórico concreto: um engajamento com o conteúdo histórico;

b) Entender características centrais de evidência, explicação e relatos históricos (tomadas para incluir noções de significância, mudança e outros conceitos-chave);

c) Adquirir as disposições (paixões racionais) que apoiam o questionamento histórico do passado.

Com respeito ao conhecimento substantivo, precisamos pensar em termos de abrigar estruturas de currículo para que os alunos possam aprender a importância da escala, e sejam capazes de se aproximar e afastar (não importa o quão desajeitado seja no inicio) dos contextos abrangentes no nível da história humana de um lado e dos estudos profundos em detalhe do outro lado. Tal estrutura permite abrigar uma típica preocupação histórica com a ação, e desconforto com generalizações, para coexistir com e se inserir em um sentido de importância de padrões mais amplos de desenvolvimento humano. Os quadros abrangentes dão um tipo importante de significância histórica aos estudos aprofundados ao localizá-los em relatos de maior escala, e os estudos aprofundados oferecem razões para se ter cautela em esperar que os quadros abrangentes sejam simplesmente transponíveis para uma escala menor, assim como permitir verificações de seu alcance e poder explicativo.

Não sabemos nada que seja suficiente sobre este conjunto de objetivos para a educação histórica, apesar das afirmações simplistas de políticos e até de alguns historiadores de que a história é somente o conhecimento de fatos. Os objetivos das pesquisas poderiam incluir:

- Exploração de conceitos substantivos dos alunos sobre como as relações humanas funcionam: conceitos-chave em áreas como o governo, impostos, direito, religião, guerra etc. (Uma boa quantidade de trabalho em algumas destas áreas parece estar aparecendo agora, mas nem sempre está relacionado às mudanças históricas nos conceitos em questão.).

- Investigação de ideias-chave que podem ser centrais para a orientação, e da maneira como elas fazem diferença em como os alunos veem as coisas. Fazem diferença em como os alunos se comportam — ou, talvez em termos mais práticos de pesquisa, no tipo de escolhas que fazem se pedirem para que decidam sobre ações ou políticas (sociais, econômicas, políticas, diplomáticas)? 
- Que suposições se interpõem no caminho dos alunos ao conectar passado, presente e futuro?

No que diz respeito ao segundo item da lista, o entendimento de segunda ordem, não estamos falando da habilidade de dar uma análise filosófica para estes conceitos, mas da habilidade (por exemplo) de usar evidência de maneiras válidas (ao invés de tratá-las como informação ou testemunho), ou ter alguma base para o julgamento alternativo de explicações, ou fazer perguntas sobre a validade de relatos concorrentes como respostas para perguntas diferentes ou similares. Observe que não são as chamadas 'habilidades' que estão em jogo aqui, mas o desenvolvimento do entendimento conceitual. O problema com pensar em termos de 'habilidades' neste contexto é que a noção de uma habilidade normalmente se refere a atividades relativamente individuais, como andar de bicicleta ou girar a madeira em um torno. Habilidades podem ser melhoradas com a prática, enquanto que atividades cognitivas mais complexas demandam um pensamento reflexivo e a prática nunca é suficiente. Aprender a pensar no contexto da tradição meta-cognitiva pode ser mais bem caracterizado em termos de adquirir habilidades, ao invés de destreza. Lógico, meramente tentar legislar sobre o uso da linguagem pode se tornar uma atividade fútil, mesmo que seja justificada pela existência de significados. Todavia há outro motivo, bem prático, para evitar o uso da fala de habilidades em conexão com a educação histórica. No Reino Unido uma abordagem genérica de história foi encorajada na escola: professores chefes de departamento se deparando com demandas para o uso ‘eficiente’ de equipes imaginam que se a história diz respeito a adquirir habilidades de comunicação, análise, ou mesmo uso de evidências, os alunos podem se apoderar de tais habilidades em outras matérias da escola. O posicionamento desleixado de professores de história ajuda a permitir o posicionamento desleixado de administradores e até de políticos. (Um aparte, poderia ser interessante perguntar até que ponto e de que maneira esta afirmação é uma 'lição’ da — recente - história, e o que isto significa sobre o quanto e dentro de que limites pode ser usada para pensar sobre o futuro.)

Sabemos mais sobre o entendimento conceitual de segunda ordem do que sobre o conhecimento substantivo, mas ainda estamos apenas no primeiro estágio da pesquisa coerente. Objetivos possíveis de pesquisa podem incluir aqui o estudo de como conceitoschave se relacionam uns com os outros (a pesquisa do Chata sugeriu que, por exemplo, o desenvolvimento de ideias sobre evidência estava dissociado do desenvolvimento de ideias sobre explicação, e, talvez mais surpreendentemente, do conceito mais intimamente ligado aos relatos). Mais interessante ainda, precisamos entender quais tipos de mudanças 
acontecem na mudança conceitual: esta última é mais bem entendida como um desenvolvimento gradual, ou mais como uma série de saltos revolucionários?

A terceira categoria na lista acima continha as disposições que precisam ser adquiridas para que as pessoas possam dizer que aprenderam história. Saber quais valores supõe-se que elas se apropriaram é um primeiro passo para entender o que a história é, mas se estes valores são meramente observados ou distraídos, então há ainda uma impressão de que a atividade ainda não foi entendida. Alguém que não se importa se frases factuais únicas colocadas sobre o passado são verdadeiras ou não, ou que não vê motivo para considerar o quão válido um relato histórico é em relação a relatos concorrentes, não aprendeu a ver o mundo historicamente. Toda esta área de educação histórica é mais ou menos território desconhecido.

O único ponto no qual ela apenas aparece na literatura é quando a 'empatia' é discutida, e com frequência serve apenas para confundir a lógica do entendimento da ação ou de conjuntos de valores e crenças do passado, por um lado, e o cuidado com as pessoas no passado, por outro. Este último é essencial, mas não é o mesmo que reafirmar nossa participação em um grupo social ou num Estado-Nação. Resumindo, o que é exigido é determinação para reconhecer as pessoas no passado como merecedoras do mesmo respeito que gostaríamos de ter, e em primeiro lugar isto significa reconhecer que eles eram tão humanos quanto nós, e existiram — foram reais — da mesma maneira que nós. E isto é verdadeiro quer estivessem 'do nosso lado' ou 'contra nós', se eles 'nos' ajudaram ou 'nos' oprimiram. O cuidado aqui significa a determinação de reconhecer que o maltrato e a resistência em nossos termos podem ou não ser a mesma coisa na passagem do passado que estamos estudando, mas que precisamos levá-lo a sério seja qual for o caso. Significa também respeitar as pessoas sobre cujos ombros o nosso mundo atual foi construído, da mesma maneira que gostaríamos de tal respeito de nossos descendentes.

A história também exige respeito pela evidência, não simplesmente como uma coleta de material para apoiar uma justificativa, mas como uma busca ativa de algo que seja provável de se mostrar problemático para o que queremos dizer. A pesquisa em psicologia cognitiva sugere que é difícil para adultos, mas não sabemos até que ponto tais dificuldades podem ser diminuídas pelo ensino direcionado. Até onde eu sei, nem sequer sabemos até que ponto as atitudes de alunos em relação à verdade e à validade, ou ao respeito pelas pessoas, muda no decorrer da educação histórica na escola.

Se nos próximos anos fosse possível discutir a fundo a concepção de literacia histórica, construída com esses e talvez outros componentes, e ganhar algum consenso dentro 
do campo da educação histórica, algumas das noções mais estreitas promulgadas por políticos e administradores pudessem sofrer melhor resistência. Um conceito de literacia histórica poderia nos avisar dos perigos de pensar que a educação em história é 'realmente' uma questão de 'conhecer os fatos', ou aprender 'a' história, ou adquirir 'habilidades'. Alguém que tenha tido educação histórica será capaz de dominar o conhecimento do passado para responder perguntas sobre acontecimentos de longas e curtas durações ocorridos no passado de maneira que atendam aos padrões de verdade e validade, serão capazes de pesar as explicações possíveis que estiverem em questão, e demonstrar, ao fazê-lo, respeito pelas pessoas do passado. Pesquisas empíricas esclarecendo o que é possível para crianças e jovens aprenderem serão extremamente importantes para levar isto adiante, mesmo que descrevessem frações de sucesso, e não listas ordenadas de resultados discretos. Mas no fundo o que está em jogo é um entendimento do nosso lugar no tempo e nossas abordagens para que o passado faça sentido: a não ser que sejamos claros sobre nossos objetivos e propósitos, a educação histórica será na melhor das hipóteses um tipo de loteria.

Tempo e Argumento: Mesmo considerando a total incapacidade de a história servir para predições, a ideia de que ela ensina "lições” ainda persiste no presente, como o senhor mesmo afirmou em artigo recentemente publicado no Brasil 'Why learn history?' (Por que aprender história?), publicado recentemente no Brasil (LEE, 2011). A ideia de que a História tem lições para ensinar não seria ainda fundamental no ensino de História para crianças e jovens?

Peter J. Lee: a resposta a esta pergunta depende realmente do que se quer dizer quando se defende que a história ensina 'lições'. Um primeiro movimento é de dizer que o passado não ensina nada, até mesmo se quisermos dizer que a história pode. Colocado de outra maneira, poderíamos saquear o passado (como a Bíblia) para apoiar quase tudo que quisermos dizer. No entanto, esta não é uma abordagem histórica do passado.

O que significaria dizer que a história pode ensinar lições?

Crianças e jovens têm uma gama limitada de experiência a qual recorrer quando querem entender como as coisas acontecem em relações humanas. O passado histórico oferece a possibilidade de experiência indireta de como tem sido possível aos seres humanos viver e se relacionar uns com os outros: por exemplo, como as instituições têm funcionado em diferentes circunstâncias, ou como os valores e crenças têm aparecido e têm sido abraçados ou rejeitados. Neste sentido — ser capaz de acessar uma ampla gama de sociedades humanas ou 
de comportamentos individuais — os alunos podem aprender por meio da história, mas eles aprendem o que foi feito, e não há garantia de que ao tentar usar tal conhecimento para pensar sobre o futuro as coisas irão dar certo.

Uma maneira de construir 'lições’ em história é pensar nelas como generalizações que podem dar apoio a previsões, mas precisamos distinguir entre os diferentes tipos de generalizações. Uma lista simplificada poderia incluir:

a) Generalizações resumindo um número finito de casos conhecidos;

b) Generalizações sobre um indivíduo;

c) Leis universais, sejam elas 'confirmadas' ou meramente 'prováveis' - isto é, 'provavelmente verdadeiras', o que envolve um sentido diferente de probabilidade daquele que se segue em (d);

d) Leis estatísticas, afirmando probabilidades numéricas - isto é, de eventos de certo tipo que ocorrem em uma população, de eventos de outro tipo;

e) Princípios de ação.

Generalizações sumativas certamente existem na história, mas elas não podem servir como base para previsões. Saber que todos os parlamentos ingleses do século XVIII eram de alguma forma - corruptos, não significa que os parlamentos do século XIX o foram, e muito menos os do século XXI. Saber que todos os pedaços de papel na minha mesa são brancos não quer dizer que todos os papéis que serão colocados lá no futuro serão brancos. A não ser que haja algo mais parecido com uma lei universal, ou pelo menos uma lei estatística, não podemos empregar uma generalização acima dos casos que ela resume.

Talvez em princípio seja possível se descobrir leis universais ou generalizações estatísticas que sejam aplicáveis à história. Alternativamente, pode-se discutir que ao dar explicações os historiadores necessariamente se comprometem com a afirmação (implícita) de que alguma lei que cobre esta explicação exista, mesmo que ninguém possa formulá-la. Entretanto, leis universais genuínas aplicáveis à história provavelmente são de baixa probabilidade, no sentido que as chances de serem verdadeiras são pequenas. Há uma razão importante para isto. Assim como não há leis na física sobre radiadores de carro que racham, que expliquem porque um radiador em particular rachou, mas do contrário leis que relacionam as mudanças de pressão de líquidos às suas temperaturas e volume, assim na história não deveríamos esperar que houvessem leis sobre a derrubada de reis ou as ações de empresários. Em história, ao contrário da física, nós não — pelo menos até agora — temos conjuntos de conceitos abstratos do tipo certo. 
Mesmo que tais esquemas conceituais fossem desenvolvidos, haveria problemas importantes sobre seu emprego na história. Isto porque a plataforma conceitual em termos de quais dos muitos eventos históricos são escolhidos e entendidos pelos agentes envolvidos é aquele prático de todo dia, no qual as coisas são feitas por razões. Até na mais plausível das análises dos motivos como causas (do tipo dado por Donald Davidson), permanecem sérias dificuldades para qualquer defesa de que possamos esperar atingir leis universais com efeitos sobre a ação humana interpretada como uma ação. Talvez pudéssemos (no futuro) ter tais leis, mas apenas pelo preço de uma nova plataforma conceitual abstrata. O preço a ser pago seria que seriamos incapazes de explicar motivos como motivos e ações como ações.

Leis estatísticas, que podem ser uma defesa melhor da verdade, são aplicáveis a uma gama limitada de áreas onde existem grandes números de eventos que podem ser encarados como 'iguais'; tipicamente eles são encontrados em história demográfica (e alguma econômica). É precisamente aí que os cientistas sociais estão fazendo algum pequeno progresso em começar a entender os padrões. Enquanto tais eventos e processos 'repetidos' são muito importantes em explicações históricas, muito da história está fora do seu escopo. O rastreamento e a explicação da contingência sempre tem sido um objetivo central da história, e, a não ser que este ideal explicativo seja abandonado, as leis estatísticas terão um papel limitado a desempenhar, mesmo que consigamos encontrá-las.

Se o argumento até aqui foi aceito, a intencionalidade e a historicidade continuam conceitos centrais na história. A ação política, movimentos ou desenvolvimentos institucionais, a manipulação econômica ou a tolerância, todos fazem referência a concepções do que está acontecendo, que são ao mesmo tempo relatos do que aconteceu. Isto é particularmente claro no caso das políticas, que necessariamente são estendidas de forma temporal. A política do Partido Conservador em relação à União Europeia (UE), por exemplo, traz com ela certo entendimento do que foi feito por e para o Reino Unido no passado, e do que foi a UE. As circunstâncias presentes são interpretadas em termos do que elas significam dentro do contexto da concepção do passado. O mesmo é verdadeiro sobre (por exemplo) a política estrangeira de Hitler, ou a política do 'Apaziguamento'. Em geral, as tradições de todos os tipos envolvem entendimentos compartilhados. Podemos pensar neles como princípios gerais que são aplicados às circunstâncias presentes, mas com frequência uma tradição é mantida na forma particularizada e concreta de um relato do que a sociedade fez e sofreu no período de sua existência.

Já que a ação futura é uma continuação de uma política (ou tradição), o conhecimento histórico pode fornecer visões de futuro ao sugerir que movimentos façam parte, ou quebrem 
esta política. Enquanto não ratifica o relato do passado consagrado em tais políticas ou tradições, cria mesmo a possibilidade de entendimento e avalição destes.

Além disso, já que qualquer ação é considerada dentro de uma situação concebida de certa maneira, o conhecimento dos elementos históricos (referência do passado) nesta situação ajudará em qualquer avaliação do que possivelmente será feito. Se pensarmos na história da UE como a história dos Estados europeus trabalhando para evitar os conflitos armados incessantes de vários países, isto levaria a expectativas sobre o desenvolvimento futuro da UE de forma diferente das que seguem de uma história de influência burocrata nas soberanias nacionais. Isto não é porque estamos fadados a esperar que a UE sempre continuará a se desenvolver como fez no passado, mas por causa de nosso entendimento modificado de como é provável que os que lideraram as políticas da UE vissem as coisas. O ponto é que para entender o que a UE está fazendo agora, e ter uma chance maior de ver o que vai fazer em seguida, é necessário saber um pouco de história. Mais além, o conhecimento histórico pode dirigir certos conceitos do passado e, portanto mudar nossa concepção de futuro - do que é possível e do que é desejável. A conexão da história com o futuro não está confinada às avaliações de probabilidades, como o que pode acontecer conosco (ou apesar de nós), mas oferece-nos uma base sobre a qual podemos decidir agir. E, é claro, já que o que é tentado é raramente o que é atingido, o conhecimento histórico pode (com o tipo de qualificações levantadas ao longo desta discussão) indicar onde procurar para ver o que pode ter importância para os eventos, sem importar o que quaisquer agentes históricos pensem estar fazendo.

Podemos ver que a noção de uma 'lição' é complexa. A possibilidade de a história oferecer lições não está somente em sua possessão de leis em geral de um tipo ou de outro. Ao lidar com a ação humana, a história sugere princípios de ação para os quais agentes humanos individuais se subscreveram, ou que operaram em sociedades humanas em tempos diferentes. Quando uma professora explica que os generais não lutam em batalhas a não ser que achem que irão vencê-las, ela está oferecendo um princípio de ação que, por si só, é simplesmente falso. No entanto, se ela está ensinando seus alunos sobre a Europa do século XVIII, quando treinar e manter tropas profissionais era extremamente caro, e a guerra estava longe de ser total, chama a atenção para o que seja provavelmente uma premissa militar importante. Como tal, mostra como era provável que a maioria dos generais se comportasse (e ao fazê-lo sugere que um general como Marlborough era diferente). Um princípio de ação é prescritível em casos individuais sem com isto ser considerado sem valor. Tais 'lições' temporalmente limitadas podem ou não se estender no futuro. Expectativas de políticas 
futuras de um partido político podem ser informadas por princípios de ação com os quais seus líderes se comprometeram no passado, mas este conhecimento não pode simplesmente ser aplicado ao futuro como se este futuro fosse se tornar apenas outro exemplo.

O conhecimento histórico pode ser visto como (entre outras coisas) uma experiência indireta: ele aponta para o que poderia ser esperado, enquanto que ao mesmo tempo torna evidente que o que é esperado é raramente exatamente o que acontece. Ele dá algum conceito da gama de possibilidades e, - se ensinado da maneira correta - abre a oportunidade de manter a reflexão deste conceito. A consciência de base da crença de alguém é apenas uma condição necessária para mantê-la sob controle, não é suficiente. E é claro que um senso de probabilidade não é uma pedra de toque do possível: uma experiência deste tipo é desastrosa se for admitida como aplicável de forma mecânica no futuro.

A história se preocupa com o estudo do passado, não do futuro, entretanto algum conhecimento do que o passado nos dá é uma forma de conquistar o futuro. Este domínio não é fortalecido ao tentar fazer da história uma fonte de previsões quase científica: ele só tem algo destacado a oferecer quando permanece ele mesmo. O ponto aqui não é que os historiadores e os que estudam história serão melhores ao desvendar o futuro do que os não historiadores, porque muitas coisas além do conhecimento da história entram nisto. O que está sendo defendido é que os indivíduos com conhecimento de história estarão melhores colocados, não do que outros indivíduos que não tenham este conhecimento, mas, do que eles mesmos sem ele.

Em todo caso, falar sobre ‘lições’ de história pode ser uma armadilha. Nada se liga no uso de 'lições' aqui, e é importante pensar sobre generalizações de vários tipos e a possibilidade de previsão na história, mas há um perigo de ficarmos presos em uma noção muito estreita de como a história muda a maneira de vermos as coisas. Talvez seja melhor pensar em termos mais amplos, e falar do poder da história de transformar a maneira como vemos o mundo. Richard Peters, o filósofo da educação, costumava dizer que poderia se pensar que um fazendeiro e um biólogo de pé em uma estrumeira no campo estavam de pé em estrumeiras diferentes. Talvez não seja exagero dizer que alguém que sabe um pouco de história irá, de alguma maneira, viver num mundo diferente daquele habitado por alguém que é em grande parte ignorante em história.

As transformações criadas pelo conhecimento histórico podem ser complexas e sutis porque elas com frequência envolvem relações recíprocas entre o passado e o presente. Nossas ideias atuais do que os humanos são e podem se tornar informam a nossa visão de, por exemplo, ideia de progresso do século dezenove, ou do Nazismo e do Holocausto, ou do 
desenvolvimento das Nações Unidas depois de 1945. O nosso entendimento destas coisas, por sua vez, modifica e enriquece nosso entendimento de quem e o que somos e podemos ser.

As lembranças podem colorir a forma como vemos as coisas. Por exemplo, depois da Segunda Guerra Mundial as ideias da geração do meu pai sobre como eram os alemães ou do que eles eram capazes, e que expectativas deveríamos ter a respeito deles no futuro, tiveram consequências para as políticas estrangeiras. Mas dentro desta geração houve diferenças importantes. Aqueles que, por exemplo, sabiam algo sobre a história alemã, estavam conscientes do impacto científico, filosófico e cultural da Alemanha antes dos Nazistas, e, portanto, viam um país e um povo bem diferente do que os que simplesmente tinham lembranças da guerra e suas origens imediatas.

A maneira como a história transforma a forma como vemos o mundo pode ser dramática. O conhecimento do passado clássico, adquirido durante o Renascimento, mudou as ideias dos Europeus do que e quem eles eram, e suas visões das possibilidades para o futuro. A consciência desenvolvida de um 'tempo profundo' no final do século dezoito e início do dezenove alterou radicalmente as ideias das pessoas sobre o tipo de mundo no qual elas estavam vivendo e dos animais que nele habitavam. Ao fazê-lo eventualmente alteraram concepções da própria humanidade.

As transformações não precisam ser tão dramáticas. Na escola a história muda como os alunos veem aspectos de seu mundo e seu lugar nele, isso pode ser mais modesto em seu alcance, mas talvez mais central para as vidas imediatas dos indivíduos. Por exemplo, alguns alunos de quinze anos de uma classe que se engajou em um 'Estudo de Desenvolvimento' no SHP de medicina, enquanto consideravam o significado de Pasteur, foram apresentados às ideias de Kuhn sobre paradigmas científicos, revoluções e resolução de enigmas. Muitos dos alunos estavam estudando conteúdos de ciências para exames, aos 16 principalmente, e no final da aula eles abordaram seus professores de história muito animados, porque sempre tinham pensado que a ciência natural fosse uma estrutura de conhecimento praticamente sem alterações, e que suas vidas como futuros cientistas consistiriam no máximo em acrescentar alguns tijolinhos extras ao edifício. Sua visão de ciência tinha sido derrubada pelo conhecimento da história: de repente viram, como um deles colocou, que 'Nós poderíamos até ser capazes de fazer uma grande diferença'. Este foi o inicio, para eles, de uma transformação radical.

A história também pode mudar como vemos o mundo ao transformar explicações, ou sugerir melhores. Armas, Germes e Aço de Jared Diamond (2007) mostra como as explicações de hegemonia Europeia em termos de superioridade cultural, sem falar em raça, 
são inadequadas. Mudanças em explicações como estas podem ter consequências para o nosso entendimento de nossa identidade e para a noção das feridas que carregamos do passado, assim como de maneira mais generalizada sobre nossas ideias de como as coisas acontecem. Alunos negros, ensinados, por professores bem intencionados, repetidas vezes sobre o triângulo-comercial, as vidas dos escravos no Sul dos Estados Unidos e a abolição da escravatura, com frequência assumem que apenas os negros foram escravizados. Todo o seu senso de quem são pode mudar quando entendem que a escravidão era uma característica normal das sociedades de baixo consumo de energia antes da invenção do motor a combustão, e que um grande número de Europeus e Asiáticos também foram escravizados. Igualmente, os alunos brancos que comodamente imaginam que os problemas dos países africanos sejam completamente autoinfligidos poderão ver o mundo de uma forma bem diferente se eles tiverem que considerar as evidências de que a escravidão durante séculos teve um papel importante na criação e manutenção desses problemas.

Algumas transformações podem ser mais 'meta-lições' do que lições. A história pode incentivar um grau de cautela, fazendo com que alunos se conscientizem do que não dizer (talvez melhor pensado como uma mudança de disposições). Pode minar as simplificações de um mundo categorizado em polaridades, ou organizado em generalizações mascaradas em forma de 'leis’ ou 'lições', muitos dos quais tiveram suas origens em 'memórias’ do passado, mas não na história. Reivindicações rudes como 'o apaziguamento agora leva às guerras depois' escolhem fazer o passado e o presente similares de maneiras relevantes, e o conhecimento histórico (também como evidência do que pode ser sensatamente afirmado sobre o presente) é necessário para testar sua validade em qualquer um dos casos. Analogias entre a migração e suas consequências no Império Romano Ocidental e a migração para alguns países da União Europeia, por exemplo, ou entre a crise financeira de 2007-2008 e recessões anteriores ou a Grande Depressão, abertamente imploram por questões sobre o passado e o presente, exigindo conhecimento histórico considerável. Sem tal conhecimento é provável que sejam incompreensíveis ou perigosamente enganadoras; com isto, elas podem nos fazer ver nosso mundo atual de maneiras novas e menos simplistas.

A transformação que a história pode oferecer nas maneiras como crianças e jovens veem as coisas pode se estender além de conteúdos específicos para concepções mais generalizados subjacentes à maneira como veem seu mundo. Sem o conhecimento histórico, as ideias dos alunos do que é normal nas relações humanas tendem a ser limitadas ao aqui e agora. Se eles virem seu mundo atual como definindo o que é normal para a vida humana, sem surpresas eles esperam que pouco mude em suas vidas futuras. As mudanças tecnológicas 
representam muito no pensamento dos alunos, mas muitos deles acham que estas mudanças estão chegando ao fim, ou pelo menos perdendo o seu impacto na vida 'comum’. Para alguns jovens de 16-17 anos de idade, por exemplo, todas as grandes invenções já foram feitas, e o futuro só trará melhorias no que já temos.

Em algumas áreas da vida humana (religião ou direito, por exemplo) ideias adultas sobre o que é normal podem fazer grandes reivindicações para alcançar o passado distante, mas com bastante frequência a normalidade é simplesmente a maneira como nós fazemos as coisas no presente. As consequências de uma noção localizada de normalidade podem parecer de formas inesperadas. Considere, por exemplo, o impacto da internet e das novas tecnologias nos hábitos de leitura. O debate sobre isto com frequência vem em forma de preocupações sobre as habilidades ou destreza entendida como as realizações 'normais' dos jovens, mas agora sob ameaça. Estas preocupações não desaparecem simplesmente com o conhecimento histórico, mas uma vez que a normalidade é considerada em um contexto histórico todo o quadro muda. Mesmo que deixemos de lado o ponto de que por longos períodos do passado muito poucas pessoas podiam ler, o conhecimento histórico coloca os assuntos sob uma luz diferente. A invenção da escrita, por exemplo, levou à perda ou diminuição de realizações e habilidades humanas importantes na memorização da origem dos mitos e das narrativas épicas centrais para a transmissão das culturas. Se a nova tecnologia está matando a leitura, as tecnologias da escrita mataram primeiro a memória oral.

Temos perfeita liberdade para dizer que todas estas transformações são 'lições' de história, mas esta forma de falar parece reduzir mudanças de perspectivas e entendimentos complexos e diferenciados a uma simplificação enganadora. Reclamar sobre o uso da palavra pode no final ser fútil, mas pedir que as pessoas tomem cuidado com o que dizem talvez seja um apelo justificável ao bom senso.

Tempo e Argumento: Apesar das reflexões sobre o Ensino de História terem avançado bastante, a dificuldade em saber como as crianças e jovens aprendem os conceitos históricos ainda permanece. Partindo da sua experiência em pesquisas, é possível apontar algumas questões que possam ser generalizadas sobre como as crianças e jovens aprendem conceitos históricos?

Peter J. Lee: Esta é uma questão enorme, e tudo o que posso fazer aqui é discutir alguns dos elementos que apareceriam em qualquer resposta abrangente. Vou tentar me restringir a algumas questões centrais. À luz mesmo da limitada pesquisa que está disponível até agora, 
os professores de história devem provavelmente abandonar a suposição de que a história é só bom senso. Por trás da história há ideias sobre como podemos saber sobre o passado, fazer relatos dele e explicar o que se passou nele. São estas ideias que determinam se a história parece ser uma forma de conhecimento que parece valer a pena para os alunos, ou algo muito estranho (grosso modo, seja algo simplesmente 'lá longe’ e dado ou algo mais como rumores, altamente inconfiável e não um conhecimento no sentido real de maneira alguma).

Alunos jovens tendem a levar as histórias sobre o passado como um dado, mas logo o bom senso lhes diz que não podemos saber sobre um passado que está morto e enterrado: não estávamos lá para ver. Mesmo quando os professores explicam que podemos falar coisas sobre o passado com base nos vestígios deixados por ele no presente, muitos alunos veem estes vestígios como sendo, na verdade, relatórios. (Se ninguém nos diz, verdadeiramente, o que aconteceu, como podemos saber?) Logo ocorre a eles que as pessoas não dizem sempre a verdade, e têm motivos para distorcer suas histórias. Portanto a história deve ser só opinião (quando não forem mentiras) — algo parecido com a definição de Ambrose Bierce de história como uma 'fofoca de bitola larga'.

O movimento crucial aqui é reconhecer que algumas ideias são mais poderosas do que outras. Algumas ideias fecham a possibilidade de história, enquanto outras permitem que prossiga, e de verdade permitem que façamos reivindicações sofisticadas e complexas sobre o passado que podem ser defendidas por referência à evidência, ao testar contra relatos rivais que tentam responder a mesma pergunta, e por apelo a critérios para boas explicações (ex. alcance, poder e coerência com outras explicações). É, portanto possível falar sem equívocos sobre ideias mais ou menos 'poderosas' em termos daquelas que param a história nas suas trilhas e as que permitem que ela vá em frente. O projeto How People Learn (Como as pessoas aprendem) nos EUA e o projeto Assessment for Learning (Avaliação para o Aprendizado) no Reino Unido destacam a importância do entendimento e de abordar as concepções anteriores dos alunos se quiser que um aprendizado útil aconteça (se opondo à mera assimilação de ideias mais poderosas do que as concepções preexistentes).

Com base nisto podemos pensar no aprendizado de história parcialmente em termos de um desenvolvimento conceitual de segunda ordem e visualizar o aprendizado como (entre outras coisas) envolvendo a progressão de ideias. Temos algum conhecimento de pesquisa sobre as ideias dos alunos sobre história e como podemos saber do passado, então os professores podem pelo menos ter algum sentido do que esperar quando eles se deparam com as concepções prévias que os alunos trazem para a escola. Os modelos de progressão produzidos por pesquisas devem ser encarados como provisórios, mas não são nada menos 
importantes por isto, já que eles permitem que os professores estejam preparados para evitar a assimilação de novas concepções que estão tentando ensinar para ideias antigas, menos poderosas que as que os alunos já possuem. Como a pesquisa desenvolve um entendimento melhor das preconcepções dos alunos, fica mais fácil para os professores preverem que tipo de mal-entendido é provável encontrarem e decidir quais destes conceitos anteriores bloqueiam o novo entendimento, e quais podem ser reforçados. (Por exemplo, a ideia que evidência histórica é equivalente a ou depende de relatórios verdadeiros bloqueia um nível mais alto de entendimento de evidência. Até que os alunos vejam que são as perguntas que ‘criam’ a evidência das fontes, é difícil para eles irem adiante, mas ideias bem simples sobre testar um relatório podem ser reforçadas para apontar o papel das perguntas, ao ajudar os alunos a usarem suas ideias existentes para reconhecer que perguntas diferentes feitas para uma fonte demandam testes diferentes. Noções relativas à 'confiabilidade’ da fonte, então, mudam já que a ‘confiabilidade’ não se liga à fonte como uma propriedade fixa desta, mas ao que pode ser dito sobre a fonte uma vez que estamos fazendo esta pergunta ao invés daquela.).

Ensinar demanda um entendimento dos desafios conceituais com os quais os alunos se deparam, e a progressão é então uma questão de mudanças conceituais, ao invés da noção simplista e imensamente danosa de se escalar uma escada de degrau em degrau. No Reino Unido tais conceitos equivocados sobre 'progressão do tipo escada' têm até levado professores a tentar ensinar o próximo nível acima em um modelo de progressão. Isto é absurdo, um modelo de progressão oferece um quadro de prováveis equívocos, portanto ensinar o 'próximo passo da escada' é, com efeito, deliberadamente ensinar aos alunos ideias equivocadas. São sempre as ideias mais poderosas que devemos tentar ensinar: a questão então é como simplificar tais ideias considerando a experiência dos alunos. (Pergunte a uma criança se há algo no seu livro didático sobre ela. Então pergunte, porque não há nada escrito sobre ela, isto significa que não podemos dizer nada de interessante a respeito dela com base em seu livro didático. A maioria das crianças com sete anos ou mais, e muitas mais novas, verão imediatamente que o fato do livro não relatar nada sobre elas não significa que não possamos responder algumas perguntas bem interessantes sobre elas. É claro, esse exemplo não trará necessariamente por si só o entendimento da evidência histórica, mas junto com outros exemplos, inclusive alguns da história, pode fazer um passo inicial importante para este objetivo.).

Conceber a progressão em termos de alterações conceituais em resposta a desafios conceituais permite que professores se perguntem quais desafios irão significar algo para seus 
alunos em particular. Isto não é sempre algo que precise ficar nas mãos do professor. Parte do aprendizado de história é o aprendizado de pensar sobre os pontos fortes e fracos das suas próprias respostas para as perguntas que estão sendo feitas, e o entendimento de segunda ordem traz com ele componentes metacognitivos. Estes podem ser colocados de maneiras relativamente diretas: se eu precisar pensar sobre estas fontes, estou sendo claro com esta pergunta que eu estou realmente tentando responder, e como isto muda as formas como eu uso esta fonte? Mas eles também podem sugerir o ensino explícito de novos conceitos, especialmente para alunos mais velhos. Quando estão tentando explicar algo no passado, alunos mais velhos podem, por exemplo, ser incentivados a pensar sobre as formas diferentes em que as explicações condicionais e contingentes funcionam. Estas ideias dão aos alunos o meio para funcionar de forma metacognitiva ao abordar explicações aparentemente rivais. Jovens que se defrontam com explicar 'a ascenção de Hitler' (talvez uma tarefa pouco eficaz) podem perguntar a si mesmos se eles estão pensando nisto em termos do que explica como 'um tipo de movimento nacional socialista ou fascista' teve sucesso na Alemanha, ou se eles estão tentando explicar porque os eventos específicos que levaram Hitler a se tornar Chanceler aconteceram. Eles podem se perguntar o que é que - por exemplo - as explicações Marxistas estão tentando fazer e como eles podem diferenciar as explicações que traçam a história de decisões específicas (dos Nazistas e seus aliados, e daqueles que se opunham a eles) que levaram Hitler ao poder.

Mais um assunto se esconde por trás de qualquer tentativa de melhorar nosso entendimento do aprendizado de história e levanta a questão do sentimento de crianças e jovens sobre se saber a respeito do passado é algo que vale a pena (mesmo se eles aceitam que isto seja possível). Precisamos lembrar que os alunos tendem a ver o passado e o presente como completamente separados (há cada vez mais provas disto, apesar de que muitos professores podem sentir que eles não precisam ter provas para algo com que se deparam com tanta frequência). Esta separação vem da avaliação do bom senso e da possibilidade do conhecimento histórico já mencionado. O passado está morto e enterrado. Como ele poderia estar ligado a algo de agora, ou mais importante ainda, com o futuro? Qual seria o ponto possível em estudá-lo? Mas poderia também haver uma ideia de senso comum funcionando aqui sobre o que é 'o presente' ('poderia', porque esta é outra lacuna nas pesquisas, apesar de estudos recentes com alunos sobre quadros abrangentes relativos à história Britânica serem sugestivos). Se o presente é concebido como quase que instantâneo, então é fácil ver como os alunos podem assumir que ele é separado do passado. Se, por outro lado, são confrontados com caracterizações do presente que carregam em si (como se fossem 'embutidas') 
referências do passado, eles podem começar a ver que o mundo no tempo é mais complicado do que eles pensavam. Descrever homens como 'casados' ou mulheres como 'viúvas', caracterizar ações do Estado como quebras de tratados, ou dizer o que um partido político 'representa', tudo pressupõe um passado, e às vezes, bastante expansivo.

Se os professores fazem perguntas aparentemente simples, como: 'Como é que no Brasil falamos português quando os países vizinhos falam espanhol e Portugal fica do outro lado do mundo?' é possível alertar os alunos para a possibilidade de que alguns aspectos do presente só podem fazer sentido se soubermos sobre o passado. Se eles perguntarem por que seu país parece ter amizade com estes povos e ser distante ou até hostil com aqueles, os alunos irão novamente achar difícil confinar seus pensamentos ao presente muito recente. E uma vez que isto seja trazido à baila, há ainda muito mais alcance para estender o 'passadopresente’ ao fazer perguntas sobre políticas de longo prazo, tradições artísticas e processos econômicos ou demográficos.

Tempo e Argumento: A preocupação com o ensino e o aprendizado em História na Educação Básica nos leva diretamente ao desafio de formar professores que sejam capazes de trabalhar não apenas com os conhecimentos substantivos, mas também os de segunda ordem. Em se tratando dos cursos de licenciatura de História esse ainda é o maior desafio, haja vista a tradição de que ensinar História é dar conta de uma lista enorme de conteúdos que remonta a Pré-História até os últimos acontecimentos da história do mundo. Em sua opinião o que poderia mudar essa tradição nos cursos de formação de professores para que estes sejam melhores preparados para ensinar história a crianças e jovens?

Peter J. Lee: provavelmente o impacto mais eficaz sobre como os professores iniciantes pensam a respeito da história pode vir de algo que não está diretamente relacionado ao dom dos formadores de professores. O que mudou as atitudes dos professores de forma mais eficaz no Reino Unido foi o desenvolvimento de exames de alto nível que exigiram que a história fosse tratada como mais do que uma absorção de fatos descritivos. Para muitos professores esta foi uma libertação de um sistema de exames que pareciam apenas planejados para tentar pegadinhas com os alunos ao perguntar a eles coisas que eles não poderiam prever ou ao pedir conhecimentos factuais inesperados sobre tópicos esperados. Tais exames foram vistos como meras loterias. Os exames do Project Schools Council History, pelo contrário, recompensaram precisamente o pensamento e o entendimento histórico que muitos professores atentos sempre tinham considerado como resultado mais importante da educação 
histórica. Porque os exames de alto nível aos 16 anos tiveram um papel tão importante na educação no Reino Unido, outros professores que não tinham participado do SCHP ficaram cada vez mais interessados, e a proporção de escolas se inscrevendo para o projeto aumentou paulatinamente. (Quando o National Curriculum foi introduzido, aproximadamente um terço das escolas tinham se inscrito naquele que era, então, conhecido como o Schools History Project.) O efeito disto na formação de professores foi considerável. As ideias que deram suporte ao SCHP já existiam antes do projeto começar, e em algumas universidades ideias similares tinham sido ensinadas para professores iniciantes. A existência de exames de alto nível aos 16 anos em busca destas ideias forçou até aqueles que eram descrentes a respeito do projeto a discutirem sobre ele em cursos de formação para professores, e a preparem os alunos para serem capazes de ensiná-los (apesar do entusiasmo contrariado e do sucesso ainda mais contrariado). Esta foi uma mudança radical.

O impacto do SCHP não parou por aí. Ele ofereceu um modelo de desenvolvimento de currículo em história que inicialmente envolvia grupos de professores que queriam fazer parte de um estudo piloto exigente, construindo e testando materiais do projeto e discutindo suas ideias. Este trabalho não foi fácil, e exigiu uma grande quantidade de tempo dos participantes, mas o entusiasmo destes professores autosselecionados contaminou os professores iniciantes para o treinamento em suas escolas e colegas em outras escolas vizinhas. O sucesso deste tipo de modelo não pode, é claro, ser admitido em todo tipo de contexto educacional nacional, mas o progresso do Projeto Historical Thinking (marco original) no Canadá parece indicar que algo em torno desta linha pode funcionar com sucesso em outros países.

Seja qual for o estado dos regimes inovadores de ensino que possam inspirar jovens professores iniciantes e incentivar os formadores de professores a repensar seus cursos, existem problemas conhecidos ao convencer as pessoas a repensar sobre o ensino de História. O mais óbvio é o de assumir que tudo o que importa para a história é que os alunos adquiram conhecimento detalhado sobre os fatos da história. Infelizmente, isto é tratado com frequência como um problema de 'método', ou de habilidade em sala de aula. Isto pode levar à visão de que a questão central no ensino seja o conhecimento da área e de uma tendência em assumir que os recém-formados terão problemas de controle de sala de aula, ou de dar um jeito de pensar em métodos entusiastas, mas que eles já ‘sabem história’.

O conhecimento do ofício é muito importante, e por um longo período foi desvalorizado (ou mesmo simplesmente um conceito com o qual as pessoas não trabalhavam), mas sem o qual considerações sérias sobre a finalidade do ensino de História, que por sua vez 
requer reflexões sobre o que é história e que lugar ela ocupa no currículo, o conhecimento do ofício é cego. Tenho que destacar mais uma vez que isto não é em detrimento do conhecimento do ofício. É verdade que sem esse conhecimento é provável que os professores se tornem impotentes, mas também é verdade que se eles não estiverem conscientes dos avanços sobre a compreensão do aprendizado humano, e mais especificamente do que é conhecido - mesmo que provisoriamente neste estágio das pesquisas - a respeito do entendimento que os alunos possuem sobre história, com frequência eles não estarão ensinando o que pensam estar.

Não é só o conhecimento empírico que está em jogo. 'As melhores práticas’ com frequência são citadas como pedra de toque para a melhoria do ensino. Mas isto é uma noção quase sem significado a não ser que haja um acordo sobre os propósitos e objetivos do ensino. Na medicina deve fazer sentido falar sobre melhores práticas, porque há um acordo sobre os resultados (as pessoas melhoram ou pioram, vivem ou morrem). Enquanto que na educação histórica muitos problemas estão nas confusões ou nas totais discordâncias sobre o que conta como educação histórica. Neste contexto, ‘melhores práticas’ são no mínimo uma ideia vazia, a não ser que os propósitos e objetivos sejam claramente estabelecidos. É por isso que o entendimento ‘teórico’ é importante. Estudantes de licenciaturas devem esperar que seus cursos os ajudem a esclarecer seu entendimento sobre história, e dar a eles acesso à pesquisa em campos relevantes. Este tipo de conhecimento pode ser mais bem descrito, não como ‘teoria’ (que tem conotações de ‘distância’ da prática), mas como conhecimento articulado ou organizado com base em algo mais do que a experiência pessoal. Como tal pode se pensar a respeito e criticar, e pode ser responsabilizado por sua base em evidências e a validade de seus argumentos, e, portanto pode ir contra as intuições muitas vezes bem locais e pessoais do conhecimento do ofício.

Saber receitas para 'métodos' de sala de aula nunca é suficiente. Se professores iniciantes tiverem um aparato para pensar sobre história, ou conhecimento de pesquisa, eles vão encarar as dificuldades reais além do ensaio de conteúdo histórico que encontraram em seus cursos de graduação. Eles podem pensar em jogos animados, encontrar vídeos divertidos, ou até organizar atividades novas de encenação, mas eles terão problemas para fazer com que tudo isto faça um trabalho histórico real, porque eles não têm ferramentas para pensar nas finalidades do ensino de História. Não é uma tarefa fácil para professores costurarem novas tarefas que valem a pena em história se não tiverem uma ideia clara do que há para atingir exceto pela entrega de informações. Para isto eles têm que receber os meios de elucidar seu próprio conceito das finalidades e propósitos do ensino de História. 
Isto pode estar ligado a um tema interessante que veio a tona nos últimos anos, a saber, a reivindicação empírica de alguns professores de História norte-americanos que a ideia de ensinar história como uma forma distinta de conhecimento (os norte-americanos tendem a usar o termo mais restrito 'disciplina', que tem a desvantagem de parecer ligar a história mais intimamente às instituições acadêmicas) não entusiasma os professores como base de reformas no ensino de História. A afirmação parece ser a de que a única forma de fazer os professores quererem a mudança é pintar a história como produtora de democratas melhores. Deixando de lado as questões conceituais, esta afirmação empírica parece bastante estranha do lado britânico do Atlântico, e até esbarra na evidência norte-americana.

Primeiro, no Reino Unido foi precisamente a ideia de ensinar história como uma forma distinta de conhecimento, separando os conceitos que davam estrutura à disciplina, que era a base do Schools Council History Project. Isto entusiasmou os professores de História de uma forma surpreendente ao dar a eles uma impressão do poder de ideias históricas que eles, por sua vez, tentaram passar para seus alunos. O SHP (como ficou) não se justificava ao apelar para promessas simplistas de fazer dos alunos democratas, apesar de muitos professores terem entendido a relação mais sutil entre os valores democráticos e os da história. Tal justificativa teria levantado suspeitas sobre a transmissão de ideologias, e poderia ter sido contraproducente. No entanto, se fechando nas reivindicações justificáveis sobre o seu impacto em como os alunos pensam a respeito da história, O SHP teve um impacto importante na educação histórica no Reino Unido, eventualmente sendo adotado em parte (mesmo sendo parcialmente entendido) em alguns aspectos do Currículo Nacional.

Segundo, nos EUA o raciocínio para a educação histórica tem sido consistentemente dado pelo apelo ao seu impacto social, com frequência desgastando o seu caráter cognitivo. Tem sido justificado para contar a história nacional e - em especial mais recentemente para fazer dos alunos melhores democratas. No entanto, é nos EUA que as reclamações no sentido de que o ensino de História não muda, e que são necessárias reformas urgentes, continuam inabaláveis por décadas. Então o apelo aos bens sociais não tem sido muito bem sucedido em incentivar uma mudança radical na educação histórica nos EUA, mas em contrapartida, o apelo para ajudar aos alunos a compreender a disciplina ou forma de conhecimento no Reino Unido foi extraordinariamente bem sucedido. Outra evidência norteamericana também traz dúvida para a reivindicação empírica. O trabalho de Seixas em um pequeno piloto em Oakland, na Califórnia, trouxe enorme entusiasmo para muitos professores participantes, mesmo quando, como nos seus correspondentes do Reino Unido nos primeiros dias do SHP, eles descobriram que a mudança seria bem difícil. O sucesso no Canadá do 
projeto Benchmarks de Seixas, agora projeto Historical Thinking, atesta que o imenso poder da ideia de ensinar história como uma forma de conhecimento é válida para professores.

Se me perdoam uma generalização selvagem, a maioria das pessoas acha algo que lhes dá poder animador, e isto inclui ideias. Se deixarmos de lado a linguagem de 'teoria' e 'prática' e reconhecermos que aprender a ensinar envolve a aquisição de um aparato conceitual e conhecimento empírico de um tipo sistemático, com frequência descobriremos que os professores iniciantes respondem com entusiasmo. O medo da gestão de sala de aula precisa ser enfrentado diretamente, para que professores jovens possam superar seus medos. Contudo, mesmo aqui é importante mostrar-lhes como os alunos que sentem que, por sua vez, estão sendo capacitados pela sua história são menos propensos para colocar desafios aos seus professores. Como os professores iniciantes concebem a história e o que eles pensam que vale a pena ensinar, assim como o conhecimento sobre os prováveis problemas de compreensão, tudo tem um efeito ‘prático’ direto na vida diária dos professores em sala de aula.

As consequências de se falhar ao dar aos professores iniciantes os meios de pensar por si próprios sobre história podem ser desastrosas. No Reino Unido temos visto isto no danoso ensino de evidência através das noções de parcialidade, ou de tratar a confiabilidade como um atributo fixo de fontes. Mais recentemente, noções confusas de significância apareceram, nas quais se assume que a significância histórica é uma propriedade fixa de eventos, ou que seja equiparada à importância humana, e listas de critérios para esta última são dadas como se elucidassem a primeira. Atualmente, e de forma mais séria, novas ideias sobre 'estruturas' e 'quadros abrangentes’ são associadas às noções preexistentes de ‘esboços' ou 'visões gerais'. Aqui e em outros lugares atividades aparentemente brilhantes de sala de aula podem na verdade diminuir o entendimento dos alunos se elas os incentivam a se ligarem em ideias de nível mais elementar ao invés de encarar os problemas que tais ideias representam.

Professores que desejam ensinar aos alunos ideias mais sofisticadas precisam ser tratados como leitores e aprendizes adultos. Se os professores iniciantes encararem apenas o conhecimento do ofício, eles estão condenados a ouvir as opiniões de todos que pedem 'experiência', inconscientes da maneira em que sua sabedoria entra em conflito com aquela das escolas vizinhas. Onde pessoas mais experientes, que permanecem limitadas desta maneira, estão em posições de influência ou autoridade, eles podem fazer danos graves, confundindo ideias que deveriam ser distinguidas, ou afirmando como fato frases sem apoio empírico válido, e oferecendo orientação espúria aos professores. 'Desempenhos' impressionantes em sala de aula podem ser parte necessária do ensino, mas não são suficientes. Algo que valha a pena e que precise ser aprendido. 
Tempo e Argumento: Você pode falar um pouco mais sobre o que tem pesquisado ultimamente?

Peter J. Lee: não há muito a dizer aqui! Eu estou agora mais ou menos aposentado, mas as áreas de interesse que estou (bem devagar e bestamente) perseguindo incluem tentativas de começar a desempacotar a ideia de uma história transformadora (que é a história como transformadora do modo como vemos o mundo), a possibilidade de pesquisar o desenvolvimento de disposições 'históricas' (por exemplo, o respeito pelas pessoas, ou pelas evidências) e a aquisição de estruturas do passado, ou de 'quadros abrangentes’ usáveis, mas históricos. Eu também tenho preocupações sobre as confusões com os objetivos, 'falas sobre habilidades’ e a redução do pensamento sobre a educação histórica no Reino Unido na produção de atividades em sala de aula com muito pouca reflexão sobre o que foi atingido.

Estou tentando ser seletivo sobre convites para escrever artigos, e ser muito seletivo sobre ir a conferências, uma vez que de muitas maneiras sinto que não tenho o suficiente a dizer que seja novo. Eu espero encontrar tempo para escrever um livro com os colegas Ros Ashby e Arthur Chapman, se eles acharem que ainda posso ser útil para produzir algum tipo de discussão.

\section{Referências}

DIAMOND, Jared. Armas, Germes e Aço: o destino das sociedades humanas. 9 ed. Rio de Janeiro: Record, 2007.

HALLDEN, Ola. Conceptual change and the learning of history. International Journal of Educational Research, v. 27, n. 3, pp. 201-210, 1997.

LEE, Peter. "Walking backwards into tomorrow": Historical consciousness and understanding história. International Journal of Historical Learning Teaching and Research, v. 4, n. 1, pp.1-46, January, 2004.

LEE, Peter. Em direção a um conceito de literacia histórica. Educar em Revista. Curitiba, volume especial, n.1, pp.131-150, 2006.

LEE, Peter. Por que aprender História? Educar em Revista. Curitiba, v. 42, n. 4, pp. 19-42, 2011.

LEE, Peter. "Nós fabricamos carros e eles tinham que andar a pé”: compreensão da vida no passado. In: BARCA, Isabel. Educação histórica e museus. Actas das segundas jornadas internacionais de educação histórica. Braga: Universidade do Minho, 2003, pp.9-18. 
SHEMILT, Denis. 'Drinking an Ocean and Pissing a Cupful: How Adolescents Make Sense of History'. In: SYMCOX, Linda.; WILSCHUT, Arie. (Eds), National História Standards The Problem of the Canon and the Future of Teaching History, volume 5 of the International Review of History Education series, Charlotte NC: Information Age Publishing, 2009, pp.141-209. 